\title{
Outcome of inflammatory breast cancer in Moroccan patients: clinical, molecular and pathological characteristics of 219 cases from the National Oncology Institute (INO)
}

Meriem Slaoui ${ }^{1,2^{*}}$ (D) Abdou Azaque Zoure ${ }^{3,4,5}$, Fatima Zahra Mouh ${ }^{1,2}$, Youssef Bensouda ${ }^{6}$, Mohammed El Mzibri ${ }^{2}$, Youssef Bakri ${ }^{7}$ and Mariam Amrani ${ }^{1}$

\begin{abstract}
Background: Usually misdiagnosed, Inflammatory Breast Cancer (IBC) is the most aggressive form of non-metastatic breast cancer. This orphan disease is more frequent in North Africa. Despite intensive treatment, the survival rate remains very low.

Methods: We have retrospectively studied all breast cancer cases diagnosed at the National Oncology Institute (INO), Rabat between 2005 and 2010. We have collected 219 cases of women with metastatic and non-metastatic IBC. Data have been obtained from patients' personal medical files over a follow-up period of 5 years. We have described IBC's clinicopathological features and analyzed its clinical outcome using SPSS software. HR (hazard Ratio) was calculated using Cox regression analysis.

Results: The frequency of IBC cases is 4.05\%. The majority of our patients (65.3\%) were under 50 years old. The most prevalent molecular subtype was Luminal A (38.7\%) followed by Luminal B HER2+ (27.9\%) and Triple negative (21.6\%).

During the follow-up period, 72 patients (32.9\%) had recurrence and 40 patients (18.3\%) died. The 3-year OS (Overall Survival) and EFS (Event Free Survival) of non-metastatic patients were 70.4 and $46.5 \%$ respectively, while in the metastatic disease, the 3-year OS was only $41.9 \%$. In non-metastatic women, we observed a higher rate of EFS associated to Selective estrogen receptor modulation treatment $(p=0.01)$, and a lower rate EFS in triple negative breast cancer patients $(p=0.02)$. In univariate analysis, we found that EFS rate is lower in patients presenting Triple Negative tumors when compared to other molecular subtypes (HR: 3.54; $95 \% \mathrm{Cl}: 1.13-11.05 ; p=0.02$ ). We also found that Selective estrogen receptor modulation treatment is associated with higher EFS rate (HR: $0.48 ; 95 \% \mathrm{Cl}: 0.07-0.59$; $p=0.01$ ).

Conclusions: IBC in Morocco shows similar characteristics to those in North African countries; however, survival rates are still the highest when compared with neighboring countries. Collaborative studies with prospective aspects are warranted to establish the epidemiological profile and understand the high frequencies of IBC in North Africa. More studies on molecular markers are also needed to improve IBC patients' management and eventually their survival rate.
\end{abstract}

Keywords: Inflammatory breast cancer, Molecular subtypes, Morocco, Overall survival, Event-free survival

\footnotetext{
* Correspondence: meriem.slaoui@um5s.net.ma

${ }^{1}$ Equipe de recherche ONCOGYMA, Faculty of Medicine and Pharmacy of

Rabat, University Mohamed V Rabat, Avenue Mohammed Belarbi El Alaoui -

Souissi - BP, 6203 Rabat, Morocco

${ }^{2} U$ nité de Biologie et Recherche Médicale, Centre National de l'Energie, des

Sciences et des Techniques Nucléaires, Rabat, Morocco

Full list of author information is available at the end of the article
}

(c) The Author(s). 2018 Open Access This article is distributed under the terms of the Creative Commons Attribution 4.0 International License (http://creativecommons.org/licenses/by/4.0/), which permits unrestricted use, distribution, and reproduction in any medium, provided you give appropriate credit to the original author(s) and the source, provide a link to the Creative Commons license, and indicate if changes were made. The Creative Commons Public Domain Dedication waiver (http://creativecommons.org/publicdomain/zero/1.0/) applies to the data made available in this article, unless otherwise stated. 


\section{Background}

Breast cancer is the most prevalent malignancy in women with more than a million and half new cases diagnosed annually [1].

Inflammatory breast cancer (IBC) is however uncommon, and considered as a rare type of breast cancer. Usually misdiagnosed, IBC is the most aggressive form of non-metastatic breast cancer [2]. IBC is characterized by rapid proliferation and several skin changes such as redness, orange skin, edema, ulceration and warmth $[3,4]$. The diagnosis of this disease is based on clinical characteristics. Despite all intensive treatments, this study population still shows a very low survival rate [5]. IBC is usually associated with negative hormone receptors especially Estrogen receptor, positive Human Epidermal Growth Factor Receptor-2 (HER2), advanced stages and more metastasis [6].

IBC is more frequent in North Africa with $5 \%$ in Morocco, 6\% in Tunisia and 11\% in Egypt, while in America, only $2.5 \%$ of breast cancers are classified as IBC [6-9]. These striking differences in IBC frequencies around the world are still misunderstood. In spite of all the scientific advances in medical research tackling this disease, the identification of risk factors directly related to IBC is inconclusive. Studies suggest that infectious agents, primarily Mouse Mammary Tumor Virus, represent the most probable etiology $[10,11]$. Various studies have reported the suspicion of risk factors such as exposure to exogenous hormones, high fat intake, ethnicity, young age, heredity and socio-economic level [12-15]. Still, none of these etiological factors have been proven to be directly linked to IBC.

IBC is still under-studied in Morocco, and to our knowledge, only one published study on this special breast cancer entity is counted [7]. For this reason, we have conducted this relatively large retrospective study of inflammatory breast cancer patients diagnosed at the National Oncology Institute (INO) in Rabat. This study aims at describing clinicopathological features, molecular characteristics and risk factors in a set of Moroccan inflammatory breast cancer patients over a period of 5 years and at analyzing prognostic factors and survival.

\section{Methods}

\section{Study design and population}

Our study population consists of Moroccan women diagnosed with breast cancer and/or followed up at the $\mathrm{Na}$ tional Oncology Institute in Rabat, Morocco from January 2005 until December 2010. A total of 5400 breast cancer patients has been recorded. Medical files have been reviewed, and confirmed inflammatory breast cancer cases have been selected for the purpose of this study. At the end, we have collected 219 cases of women diagnosed with metastatic and non-metastatic inflammatory breast cancer.
Inclusion criteria: all Moroccan women diagnosed with IBC during the study period at the National Oncology Institute. We have excluded patients with incomplete medical files and patients without histological confirmation of breast cancer.

Patients' ages ranged between 26 to 75 years. The mean age of women at diagnosis was $47 \pm 10.3$.

\section{Data collection}

Data has been obtained from patients' personal medical files. The medical records have then been retrospectively reviewed and collected using SPSS-software 13.0. For each case, we have collected all information on age, parity, body mass index, hormonal status, familial history of breast cancer, clinical as well as pathological data, and follow-up.

Histological type has been updated according to the WHO classification of breast tumors of 2012 (World Health Organization) [16]. Tumor pTNM (pathological Tumor Node Metastasis) staging is consistent with the seventh edition of AJCC classification (American Joint Committee on Cancer) of 2009. Tumor grade has been assessed according to Scarff-Bloom \& Richardson (SBR) grading system, amended by Ellis and Elston [17].

Estrogen and Progesterone receptors (ER and PR) were considered positive when at least $10 \%$ of the tumor cells showed nuclear expression.

Immuno-histo-chemical expression of Her 2 has been defined based on cytoplasmic membrane staining of the infiltrative component according to the American Society of Clinical Oncology (ASCO) [18]. Fluorescent in situ hybridization (FISH) has been performed to assess Her 2 amplification in 2+ borderline cases.

According to ER, PR and Her2 status, breast cancer cases have been classified into five subgroups: Luminal A (ER $+/ \mathrm{PR}+/$ Her2-), Luminal B Her2- (ER+/PR- or lower than $20 \%$ /Her2-), Luminal B Her+ (ER+/PR+ or - /Her2+), Her2 (ER-/PR-/Her2+) and triple negative (ER-/PR-/Her2-) [19].

Treatment data such as: surgery type (total mastectomy/ Partial mastectomy), chemotherapy, radiotherapy, targeted therapy and hormone therapy have been collected from patients' medical files. During the study period, selective estrogen receptor modulators (SERM) were being used as hormone therapy.

\section{Follow-up}

Patients were followed up until December 2012. Event free survival (EFS) was calculated from the date of neoadjuvant chemotherapy to the date of loco-regional recurrence or distant metastasis. Overall survival (OS) was calculated from the date of histological diagnosis to the date of death. The follow-up was carried out by checking the status of patients in their personal medical files. 


\section{Statistical analysis}

Statistical analysis has been assessed by SPSS 13.0 software (IBM), while descriptive variables have been expressed as means \pm SD. Calculation of survival rates has been performed by the Kaplan-Meier method and compared using the Log-rank test. Patients lost to follow-up were considered as a censored event.

Hazard ratios have been calculated using Cox regression analysis and assumptions of Cox proportional hazards regression were checked graphically using "log-log" plots.

\section{Results}

\section{Clinical and pathological data}

The mean age in our series was $47 \pm 10$. 3 years with extreme ages of 26 years and 75 years. Clinical and pathological results are listed in Tables 1 and 2 . The majority of our patients $(65.3 \%)$ were aged under 50 years. Only $31.4 \%$ were nulliparous and almost half of the patients had more than three full-term pregnancies. Pre-menopausal women were as many as post-menopausal women; only $35.3 \%$ of patients had normal body mass index, while $63.5 \%$ were overweight or obese.

At the time of diagnosis, sixty-six women had metastatic disease (30.1\%). The most prevalent molecular subtype was Luminal A (38.7\%) followed by Luminal B HER2+ (27.9\%) and Triple negative (21.6\%).

Mean tumor size was $6.27 \mathrm{~cm}$, and the majority of patients $(52.3 \%)$ had tumors sized more than $5 \mathrm{~cm}$. Vascular invasion was found in 119 patients (54.3\%). High SBR (SBR II and SBR III) grades were observed in $92.9 \%$ of the tumors, and most of patients had invaded axillary lymph nodes (69.9\%).

\section{Treatment}

Neoadjuvant chemotherapy was administered to $95.4 \%$ of patients: $70.3 \%$ received Anthracyclines-based chemotherapy, 23.9\% received Anthracyclines and taxanes regimen and only $5.7 \%$ took taxanes only. 125 women (57.1\%) underwent radical surgery. Adjuvant chemotherapy and Herceptine were administered respectively in 22.8 and $17.4 \%$ of the cases. After surgery, $47.5 \%$ of the patients received radiotherapy while only $28.3 \%$ received SERM (Table 3).

\section{Survival and outcome}

Median follow-up was 13 months with a range of 163 months. During the follow-up period, 72 patients (32.9\%) had recurrence and 40 patients (18.3\%) died, while 19 patients $(8.67 \%)$ were lost to follow-up. The results of Kaplan-Meier analysis are reported in Fig. 1. The 3-year OS and EFS of non-metastatic patients were 70.4 and $46.5 \%$ respectively, while in metastatic disease, the 3 -year OS was only $41.9 \%$ (Fig. 1). In non-metastatic
Table 1 Clinical data in all inflammatory breast patients

\begin{tabular}{|c|c|c|}
\hline Variables & Number of patients & percentage (\%) \\
\hline \multicolumn{3}{|l|}{ Age } \\
\hline$<30 y$ & 13 & 5.9 \\
\hline $31-40$ & 46 & 21.0 \\
\hline $41-50$ & 84 & 38.4 \\
\hline$>50 y$ & 76 & 34.7 \\
\hline \multicolumn{3}{|l|}{ Nulliparity } \\
\hline Yes & 66 & 31.4 \\
\hline No & 144 & 68.6 \\
\hline Unknown & 9 & - \\
\hline \multicolumn{3}{|c|}{ Number of full-term pregnancies } \\
\hline 0 & 66 & 31.5 \\
\hline $1-2$ & 43 & 20.6 \\
\hline $3-4$ & 48 & 23.0 \\
\hline$\geq 5$ & 52 & 24.9 \\
\hline Unknown & 10 & - \\
\hline \multicolumn{3}{|l|}{ Menopausal staus } \\
\hline Pre-menopausal & 113 & 51.6 \\
\hline Post-menopausal & 106 & 48.4 \\
\hline \multicolumn{3}{|l|}{ Familial history of BC } \\
\hline Yes & 28 & 26.2 \\
\hline No & 79 & 73.8 \\
\hline Unknown & 112 & - \\
\hline \multicolumn{3}{|l|}{ BMl } \\
\hline Underweight & 2 & 1.2 \\
\hline Normal & 60 & 35.3 \\
\hline Overweight & 50 & 29.4 \\
\hline Obese & 58 & 34.1 \\
\hline Unknown & 49 & - \\
\hline \multicolumn{3}{|l|}{ Peau d'orange } \\
\hline Yes & 155 & 70.8 \\
\hline No & 64 & 29.2 \\
\hline \multicolumn{3}{|l|}{ Oedema } \\
\hline Yes & 45 & 20.5 \\
\hline No & 174 & 79.5 \\
\hline \multicolumn{3}{|l|}{ Redness } \\
\hline Yes & 100 & 54.3 \\
\hline No & 119 & 45.7 \\
\hline \multicolumn{3}{|l|}{ Palpable mass } \\
\hline Yes & 55 & 25.1 \\
\hline No & 164 & 74.9 \\
\hline \multicolumn{3}{|l|}{ Side } \\
\hline Right breast & 102 & 46.6 \\
\hline Left breast & 115 & 52.5 \\
\hline Bilateral & 2 & 0.9 \\
\hline
\end{tabular}


Table 1 Clinical data in all inflammatory breast patients (Continued)

\begin{tabular}{lll}
\hline Variables & Number of patients & percentage (\%) \\
\hline Metastatic disease & & \\
Yes & 66 & 30.1 \\
No & 153 & 69.9 \\
\hline
\end{tabular}

women, we observed a higher EFS rate associated to SERM treatment with a significant difference $(p=0.01)$, and a lower EFS rate in TNBC patients $(p=0.02)$, while the other parameters did not show significant results in Kaplan-Meier analysis.

Univariate and multivariate analysis of EFS and OS are represented in Table 4. In univariate analysis, we found that EFS rate is lower in patients presenting left breast tumors or bilateral tumors (HR: 1.92; 95\%CI: 1.07-3.44; $p=$ 0.02 - HR: 10.32; 95\%CI: $1.32-80.47 ; p=0.02)$, and TNBC tumors when compared to other molecular subtypes (HR: 3.54; 95\%CI: $1.13-11.05 ; p=0.02)$. We also found that SERM treatment is associated with a higher EFS rate (HR: 0.48; 95\%CI: $0.07-0.59 ; p=0.01)$. The multivariate model shows that the EFS rate in non-metastatic patients is higher in women aged more than 50 years (HR: 0.06; 95\%CI: $0.00-0.61 ; p=0.01)$ and in patients treated with SERM (HR: 0.09; 95\%CI: 0.01-0.72; $p=0.02$ ). Univariate analysis for OS did not demonstrate significant associations and no parameter showed close statistical significance (Table 4).

\section{Discussion}

In this study, we have intended to investigate IBC's clinical, molecular and pathological features, and analyze survival in Moroccan patients diagnosed with IBC between 2005 and 2010.

IBC is more frequent in North African countries, especially in Tunisia and Egypt where frequencies are 5 and $6 \%$ respectively. In our series, the frequency of IBC cases was $4.05 \%$, which agrees with a previous study conducted at the same institute where authors have found an occurrence of $5 \%$ of all breast cancer cases [7].

A number of important epidemiological studies have found that IBC occurs at a younger age than non-inflammatory breast cancer [10]. Indeed, $65.3 \%$ of our IBC patients were younger than 50 years, while in Algeria the percentage was $59.8 \%$. On the other hand, the National Cancer Institute's Surveillance, Epidemiology, and End Results (SEER) program has shown that only $34.7 \%$ of IBC patients were aged less than 50 years [20]. We have also noted some differences in median age between Algerian, Tunisian, Moroccan and American IBC series. Tunisian patients represent the youngest age with a median age of 43.5 years [21], followed by Moroccan and Algerian patients with a median age of 47 years and 48.5 years,
Table 2 pathological data in inflammatory breast cancer tumors

\begin{tabular}{|c|c|c|}
\hline Variables & Number of patients & Percentage (\%) \\
\hline \multicolumn{3}{|l|}{ ER } \\
\hline Positive & 99 & 55.6 \\
\hline Negative & 79 & 44.4 \\
\hline Unknown & 41 & - \\
\hline \multicolumn{3}{|l|}{$\mathrm{PgR}$} \\
\hline Positive & 124 & 69.7 \\
\hline Negative & 54 & 30.3 \\
\hline Unknown & 41 & - \\
\hline \multicolumn{3}{|l|}{ Her2 } \\
\hline Positive & 41 & 35.3 \\
\hline Negative & 75 & 64.7 \\
\hline Unknown & 103 & - \\
\hline \multicolumn{3}{|l|}{ Molecular subtype } \\
\hline Luminal A & 43 & 38.7 \\
\hline Luminal B Her2 - & 5 & 4.5 \\
\hline Luminal B Her2 + & 31 & 27.9 \\
\hline Her2 & 8 & 7.2 \\
\hline Triple negative & 24 & 21.6 \\
\hline Unknown & 108 & - \\
\hline \multicolumn{3}{|l|}{ Tumor size } \\
\hline$\leq 20 \mathrm{~mm}$ & 27 & 15.7 \\
\hline $21-50 \mathrm{~mm}$ & 55 & 32.0 \\
\hline$>50 \mathrm{~mm}$ & 90 & 52.3 \\
\hline Unknown & 47 & - \\
\hline \multicolumn{3}{|l|}{ Lymph nodes } \\
\hline NO & 66 & 30.1 \\
\hline $\mathrm{N} 1$ & 84 & 38.4 \\
\hline N2 & 45 & 20.5 \\
\hline N3 & 24 & 11.0 \\
\hline \multicolumn{3}{|l|}{ Histological type } \\
\hline Invasive carcinoma of NST & 212 & 96.8 \\
\hline Invasive lobular carcinoma & 4 & 1.8 \\
\hline Others & 3 & 1.4 \\
\hline \multicolumn{3}{|l|}{ Vascular invasion } \\
\hline Yes & 119 & 54.3 \\
\hline No & 100 & 45.7 \\
\hline \multicolumn{3}{|l|}{ SBR grade } \\
\hline SBR I & 15 & 7.1 \\
\hline SBR ॥ & 110 & 52.1 \\
\hline SBR III & 86 & 40.8 \\
\hline Unknown & 8 & - \\
\hline
\end{tabular}


Table 3 Treatment data for IBC cases

\begin{tabular}{lcl}
\hline Treatment & Number of patients & Percentage (\%) \\
\hline Neoadjuvant & Chemotherapy & 95.4 \\
Yes & 209 & 4.6 \\
No & 10 & \\
Mastectomy & & 57.1 \\
Yes & 125 & 42.9 \\
No & 94 & \\
Adjuvant Chemotherapy & 22.8 \\
Yes & 50 & 77.2 \\
No & 169 & \\
Herceptine & & 17.4 \\
Yes & 38 & 82.6 \\
No & 181 & \\
Radiotherapy & & 47.5 \\
Yes & 104 & 52.5 \\
No & 115 & 28.3 \\
SERM treatment & & 71.7 \\
Yes & 62 & \\
No & 157 & \\
\hline
\end{tabular}

respectively [7, 22]. Whereas American patients from the SEER program have shown the higher median age, 56 years [20]. These comparisons show that IBC might occur at younger age in North African populations compared to the American one. We may explain these differences by the possible viral etiology especially Mouse Mammary Tumor Virus Like (MMTV-Like) as described in previous studies led in this area $[23,24]$.

IBC diagnosis is entirely clinical and well established by AJJC; it is based on the presence of inflammatory signs especially diffuse erythema and oedema of the breast with or without an underlying mass. In the present study, palpable mass was detected in only $25.1 \%$ as compared to the Algerian series where it was detected in $31.9 \%$ of patients, while in Tunisian patients, the majority of women (76\%) had palpable mass at the time of diagnosis [21, 22]. Once again, the Tunisian population shows a different aspect from the Algerian and Moroccan populations.

High BMI is considered as a risk factor for IBC and has been analyzed in several studies but the results are not conclusive $[12,21,25,26]$. In the Tunisian series, $42 \%$ of IBC patients were obese while in our study we have registered a percentage of $34.1 \%$. Data from the Breast Cancer Surveillance Consortium (BCSC) shows that $32.2 \%$ of IBC patients had a high BMI [26]. In a French study, we note that IBC patients are less obese, and only $21 \%$ of patients presented high BMI [12]. Furthermore, results from a comparative study between North-African series show no significant difference in
BMI between IBC and non-IBC patients, but the authors still insist on the need for further studies because of the increasing incidence of obesity among women in North Africa [27].

IBC is known to show pejorative pathological characteristics. Therefore, we have found that $84.3 \%$ of the tumors measured more than $2 \mathrm{~cm}$ in greatest diameter, which joins the Algerian study findings with $88 \%$ of large sized tumors [22]. High SBR grades (SBR II and SBR III) were found in $92.9 \%$ of our IBC patients, $80.2 \%$ of SEER population [20], $76 \%$ of Tunisian patients [21], and $100 \%$ of Algerian and Egyptian patients [22, 27]. The comparative study between North African countries (Egypt, Tunisia and Morocco) demonstrate no statistical difference regarding SBR grades [27]. At the molecular level, many studies have documented that IBC is usually correlated to negative hormone receptors and positive HER2 status, which confers to this disease its aggressiveness [2]. The Tunisian study has shown that $52 \%$ of IBC tumors were ER-/PR- [28], while in Egypt only 38.9\% of the tumors were negative for hormone receptors [27]. The lack of expression of hormone receptors in the Algerian study was $26.7 \%$ for ER and $71.8 \%$ for PR [22], while in our study IBC tumors were ER- in $44.4 \%$ and PR- in $30.3 \%$. According to the comparative study, these disparities between North African countries did not show a significant difference [27].

Studies suggest that about $20 \sim 40 \%$ of IBC cases are triple negative breast cancers [2, 22, 29], which has a worse prognosis and lower survival rates than other breast cancer subtypes. Our study has shown the same range with $21.6 \%$ of TNBC tumors, and EFS was also at a lower rate in the TNBC subgroup compared to the other molecular subgroups with a significant difference $(p=0.02)$. The investigation of the seven triple negative subtypes, as described in Lehmann study (basal-like 1 (BL1), basal-like 2 (BL2), immunomodulatory (IM), mesenchymal (M), mesenchymal stem-like (MSL), luminal androgen receptor (LAR), and unstable (UNS)), could contribute to resolving the differing clinical behavior when IBC and TNBC coexist [30, 31].

Interestingly and as in the Algerian study [22], the most prevalent subtype in our series was Luminal A followed by luminal B HER2+, unlike the Tunisian study where the most prevalent subtype was TNBC followed by HER2 subtype [32]. Molecular differences between these neighboring countries might be due to environmental and genetic factors that vary from an area to another. Further collaborative studies between these countries are needed.

The role of adjuvant endocrine therapy in the survivorship of IBC patients was clearly investigated in several clinical trials and concluded that SERM treatment is as efficient as chemotherapy in premenopausal breast cancer 

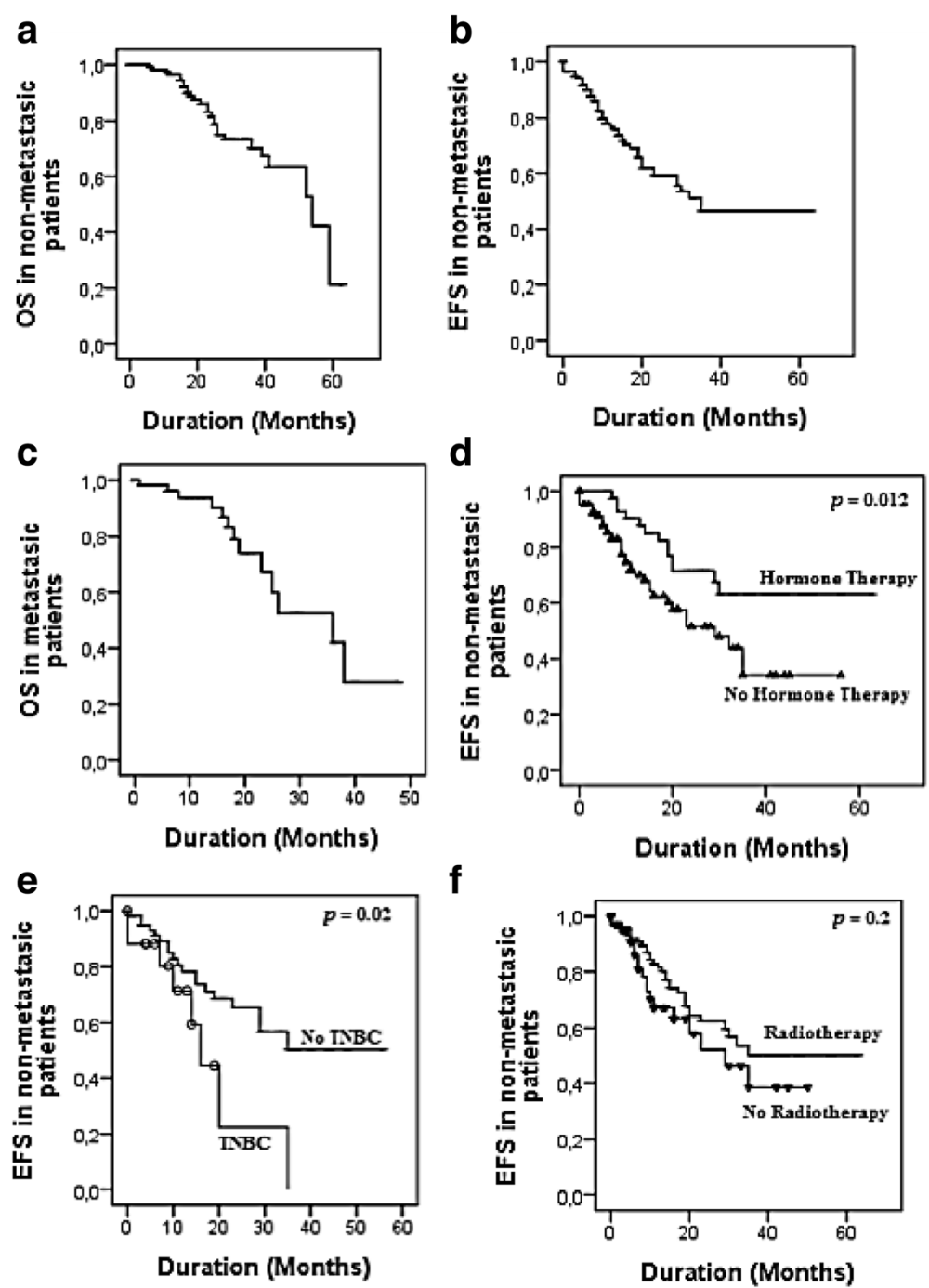

$\mathbf{f}$

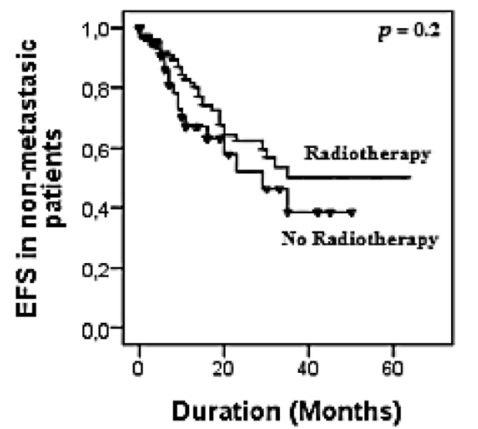

Fig. 1 Outcomes (OS and/or EFS) in metastatic and non-metastatic IBC patients (a, b and $\mathbf{c}$ ), EFS in TNBC patients (e), and impact of Hormone therapy and Radiotherapy (d and f). (OS: Overall survival; EFS: Event-Free Survival)

patients [21,33]. Our study as well as the Tunisian one shows a significant better EFS in IBC patients who received adjuvant SERM treatment [21].

Contrastingly, the survival rates are higher in our series compared to the Tunisian study. In fact, the 3 -year OS and EFS in our series were 70.4 and $46.5 \%$ respectively, while in Tunisia rates were 44 and $28 \%$, respectively. This difference is mostly due to the lack of supportive care services and the absence of access to new drugs such as taxanes during the 1990's, which corresponds to the period of study in Tunisian series [21].

Our study has several strengths. First, the number of patients with IBC is relatively large. Second, the large period that was taken to select participants extended over 6 years. Furthermore, our study represents the first large study including clinical, epidemiological, pathological and molecular characteristics of IBC in Moroccan patients.
This study has also limitations due to its retrospective aspect. Lack of data in some parameters is the major limitation. In addition, the study has been conducted in a single institution. Although it is the reference center of oncology in Morocco, our patients are not representative of the population. We also believe that short median follow-up and loss to follow-up rates could have influenced our survival rates. Finally, socioeconomic conditions have not been investigated, which might have limited access to some drugs like taxanes and Trastuzumab.

\section{Conclusions}

IBC in Morocco shows similar characteristics to those in North African countries; however, survival rates are still the highest when compared with neighboring countries. Collaborative studies with prospective aspects are warranted to establish the epidemiological profile and 
Table 4 Univariate and Multivariate Cox analysis for Overall survival and Event-Free Survival in non-metastatic patients

\begin{tabular}{|c|c|c|c|c|c|c|c|c|c|}
\hline \multirow[t]{3}{*}{ Parameters } & \multicolumn{6}{|c|}{ Event Free Survival } & \multirow{2}{*}{\multicolumn{3}{|c|}{$\frac{\text { Overall Survival }}{\text { Univariate analysis }}$}} \\
\hline & \multicolumn{3}{|c|}{ Univariate analysis } & \multicolumn{3}{|c|}{ Multivariate analysis } & & & \\
\hline & $\mathrm{HR}$ & $95 \% \mathrm{Cl}$ & $p$ & $\overline{\mathrm{HR}}$ & $95 \% \mathrm{Cl}$ & $p$ & $\overline{\mathrm{HR}}$ & $95 \% \mathrm{Cl}$ & $p$ \\
\hline \multicolumn{10}{|l|}{ Side } \\
\hline Right breast & 1 & & & 1 & & & 1 & & \\
\hline Left breast & 1.92 & $1.07-3.44$ & 0.02 & 2.87 & $0.98-8.42$ & 0.05 & 1.36 & $0.61-3.01$ & 0.44 \\
\hline Bilateral & 10.32 & $1.32-80.47$ & 0.02 & - & - & - & 5.14 & $0.65-40.65$ & 0.12 \\
\hline \multicolumn{10}{|l|}{ Obesity $^{a}$} \\
\hline No & 1 & & & 1 & & & 1 & & \\
\hline Yes & 1.36 & $0.72-2.54$ & 0.33 & 1.45 & $0.55-3.85$ & 0.44 & 1.80 & $0.76-4.27$ & 0.17 \\
\hline \multicolumn{10}{|l|}{ SBR Grade } \\
\hline 1 & 1 & & & & & & 1 & & \\
\hline$\|$ & 0.63 & $0.18-2.16$ & 0.46 & & & & 0.67 & $0.14-3.09$ & 0.61 \\
\hline III & 1.33 & $0.40-4.38$ & 0.63 & - & - & - & 1.00 & $0.22-4.48$ & 0.99 \\
\hline \multicolumn{10}{|l|}{ N status } \\
\hline N- & 1 & & & & & & 1 & & \\
\hline $\mathrm{N}+$ & 1.55 & $0.79-3.04$ & 0.19 & - & - & - & 1.55 & $0.61-3.91$ & 0.35 \\
\hline \multicolumn{10}{|l|}{$\mathrm{Age}^{\mathrm{a}}$} \\
\hline$<30 y$ & 1 & & & 1 & & & 1 & & \\
\hline $31-40$ & 0.89 & $0.29-2.67$ & 0.84 & 0.24 & $0.03-1.86$ & 0.17 & 2.60 & $0.32-20.76$ & 0.36 \\
\hline $41-50$ & 0.66 & $0.22-1.97$ & 0.46 & 0.20 & $0.02-1.60$ & 0.12 & 1.29 & $0.16-10.42$ & 0.81 \\
\hline >50y & 0.62 & $0.20-1.95$ & 0.46 & 0.06 & $0.00-0.61$ & 0.01 & 2.18 & $0.25-18.36$ & 0.47 \\
\hline \multicolumn{10}{|l|}{ ER } \\
\hline Negative & 1 & & & & & & 1 & & \\
\hline Positive & 0.69 & $0.38-1.27$ & 0.23 & - & - & - & 2.05 & $0.85-4.98$ & 0.11 \\
\hline \multicolumn{10}{|l|}{ PgR } \\
\hline Negative & 1 & & & & & & 1 & & \\
\hline Positive & 0.88 & $0.46-1.66$ & 0.69 & - & - & - & 1.03 & $0.42-2.53$ & 0.94 \\
\hline \multicolumn{10}{|l|}{ Her2 } \\
\hline Negative & 1 & & & & & & 1 & & \\
\hline Positive & 0.77 & $0.35-1.70$ & 0.53 & - & - & - & 0.42 & $0.04-3.81$ & 0.44 \\
\hline \multicolumn{10}{|l|}{ Molecular subtype ${ }^{a}$} \\
\hline Luminal A & 1 & & & 1 & & & 1 & & \\
\hline Luminal B Her2 - & 2.57 & $0.68-9.64$ & 0.16 & 0.86 & $0.15-4.82$ & 0.86 & 2.57 & $0.78-2.60$ & 0.98 \\
\hline Luminal B Her2 + & 1.78 & $0.59-5.34$ & 0.29 & 0.31 & $0.07-1.34$ & 0.11 & 0.43 & $0.04-4.23$ & 0.47 \\
\hline Her2 & 0.57 & $0.06-4.91$ & 0.61 & 0.11 & $0.01-1.18$ & 0.06 & 0.57 & $0.05-3.81$ & 0.98 \\
\hline Triple negative & 3.54 & $1.13-11.05$ & 0.02 & 1.72 & $0.47-6.31$ & 0.41 & 1.99 & $1.10-10.00$ & 0.96 \\
\hline \multicolumn{10}{|l|}{ Surgery ${ }^{a}$} \\
\hline No & 1 & & & 1 & & & 1 & & \\
\hline Yes & 0.73 & $0.39-1.39$ & 0.34 & 1.13 & $0.37-3.49$ & 0.82 & 0.62 & $0.23-1.70$ & 0.36 \\
\hline \multicolumn{10}{|l|}{ Radiotherapy ${ }^{a}$} \\
\hline No & 1 & & & 1 & & & 1 & & \\
\hline Yes & 1.20 & $0.9-1.6$ & 0.21 & 0.88 & $0.28-2.73$ & 0.82 & 1.23 & $0.81-1.87$ & 0.32 \\
\hline \multicolumn{10}{|l|}{ SERM treatment } \\
\hline No & 1 & & & 1 & & & 1 & & \\
\hline
\end{tabular}


Table 4 Univariate and Multivariate Cox analysis for Overall survival and Event-Free Survival in non-metastatic patients (Continued)

\begin{tabular}{|c|c|c|c|c|c|c|c|c|c|}
\hline \multirow[t]{3}{*}{ Parameters } & \multicolumn{6}{|c|}{$\underline{\text { Event Free Survival }}$} & \multirow{2}{*}{\multicolumn{3}{|c|}{$\begin{array}{l}\text { Overall Survival } \\
\text { Univariate analysis }\end{array}$}} \\
\hline & \multicolumn{3}{|c|}{ Univariate analysis } & \multicolumn{3}{|c|}{ Multivariate analysis } & & & \\
\hline & $\mathrm{HR}$ & $95 \% \mathrm{Cl}$ & $p$ & $\mathrm{HR}$ & $95 \% \mathrm{Cl}$ & p & $\mathrm{HR}$ & $95 \% \mathrm{Cl}$ & $p$ \\
\hline Yes & 0.48 & $0.07-0.59$ & 0.01 & 0.09 & $0.01-0.72$ & 0.02 & 1.01 & $0.69-1.49$ & 0.92 \\
\hline
\end{tabular}

${ }^{a}$ : variables being adjusted for the multivariate model; significant $p$ values are in boldface

understand the high frequencies of IBC in North Africa. More studies on molecular markers are also needed to improve IBC patients' management and eventually their survival rate.

\section{Abbreviations}

AJCC: American Joint Committee on Cancer; BC: Breast cancer;

Cl: Confidence interval; EFS: Event free survival; ER: Estrogen receptor;

FISH: Fluorescent in situ hybridization; Her2: Human epidermal growth factor receptor 2; HR: Hazard ratio; IBC: Inflammatory Breast Cancer;

IHC: Immunohistochemistry; LN: Lymph nodes; NST: No Special Type;

PgR: Progesterone receptor; pTNM: Pathological Tumor Node Metastasis;

SBR: Scarff-Bloom Richardson classification; SERM: Selective estrogen receptor modulation; TNBC: Triple negative breast cancer; WHO: World Health Organization

\section{Acknowledgements}

We thank Dr. Erraki Mohamed from the epidemiology unit at the National Institute of Oncology and his team for providing us necessary medical records needed for the study.

\section{Availability of data and materials}

The datasets used and/or analysed during the current study are available from the corresponding author on reasonable request.

\section{Authors' contributions}

SM exploited data, analyzed data, conducted statistical analysis, wrote and drafted the manuscript; AAZ and FZM co-exploited data and drafted the manuscript; YB co-exploited data and interpreted data; MEM and YB contributed revising and critical drafting of the manuscript; MA conceived and coordinated the study, and drafted the manuscript. All authors have approved the final manuscript for publication.

\section{Ethics approval and consent to participate}

The Ethical Committee of Biological Research, Faculty of Medicine and Pharmacy - Rabat, approved the study under the reference number 325/13, and no consent was needed because of the retrospective aspect of the study. The present publication does not compromise anonymity or confidentiality or breach local data protection laws.

\section{Consent for publication}

Not applicable.

\section{Competing interests}

The authors declare that they have no competing interests.

\section{Publisher's Note}

Springer Nature remains neutral with regard to jurisdictional claims in published maps and institutional affiliations.

\section{Author details}

${ }^{1}$ Equipe de recherche ONCOGYMA, Faculty of Medicine and Pharmacy of Rabat, University Mohamed V Rabat, Avenue Mohammed Belarbi El Alaoui Souissi - BP, 6203 Rabat, Morocco. ${ }^{2}$ Unité de Biologie et Recherche Médicale, Centre National de l'Energie, des Sciences et des Techniques Nucléaires, Rabat, Morocco. ${ }^{3}$ Pietro Annigoni Biomolecular Research Center (CERBA)/ LABIOGENE, University of Ouaga 1 Joseph KI ZERBO, UFR/SVT, Ouagadougou, Burkina Faso. ${ }^{4}$ Laboratory of Biochemistry and Immunology, Faculty of Sciences, University of Mohammed V-Rabat, Rabat, Morocco. ${ }^{5}$ Institute of
Health Sciences Research, (IRSS)/ Department of Biomedical and Public Health, Ouagadougou, Burkina Faso. ${ }^{6}$ Faculty of Medicine and Pharmacy of Rabat, University Mohamed V Rabat, Avenue Mohammed Belarbi El Alaoui Souissi - BP, 6203 Rabat, Morocco. ${ }^{7}$ Biochemistry-Immunology Laboratory, Faculty of Sciences Rabat, University Mohammed V - Agdal, Rabat, Morocco.

Received: 24 October 2017 Accepted: 25 June 2018

Published online: 05 July 2018

References

1. GLOBOCAN: Estimated incidence, mortality and prevalence worldwide in 2012. 2012.

2. Dawood S, Merajver S, Viens P, Vermeulen P, Swain S, Buchholz T, Dirix L, Levine P, Lucci A, Krishnamurthy S. International expert panel on inflammatory breast cancer: consensus statement for standardized diagnosis and treatment. Ann Oncol. 2011;22(3):515-23. https://doi.org/10.1093/annonc/mdq345.

3. Jaiyesimi IA, Buzdar AU, Hortobagyi G. Inflammatory breast cancer: a review. J Clin Oncol. 1992;10(6):1014-24.

4. Tabbane F, Bahi J, Rahal K, May AE, Riahi M, Cammoun M, Hechiche M, Jaziri M, Mourali N. Inflammatory symptoms in breast cancer. Correlations with growth rate, clinicopathologic variables, and evolution. Cancer. 1989;64(10): 2081-9.

5. Gonzalez-Angulo AM, Hennessy BT, Broglio K, Meric-Bernstam F, Cristofanilli M, Giordano SH, Buchholz TA, Sahin A, Singletary SE, Buzdar AU. Trends for inflammatory breast cancer: is survival improving? Oncologist. 2007:12(8):904-12.

6. Hance KW, Anderson WF, Devesa SS, Young HA, Levine PH. Trends in inflammatory breast carcinoma incidence and survival: the surveillance, epidemiology, and end results program at the National Cancer Institute. J Natl Cancer Inst. 2005;97(13):966-75.

7. Ismaili N, Elyaakoubi H, Bensouda Y, Errihani H. Demographic, clinical, pathological, molecular, treatment characteristics and outcomes of nonmetastatic inflammatory breast cancer in Morocco: 2007 and 2008. Exp Hematol Oncol. 2014;3(1):1.

8. Boussen $H$, Bouzaiene $H$, Ben Hassouna J, Dhiab T, Khomsi F, Benna F, Gamoudi A, Mourali N, Hechiche M, Rahal K. Inflammatory breast cancer in Tunisia. Cancer. 2010;116(S11):2730-5.

9. Soliman AS, Banerjee M, Lo A-C, Ismail K, Hablas A, Seifeldin IA, Ramadan M, Omar HG, Fokuda A, Harford JB. High proportion of inflammatory breast cancer in the population-based Cancer registry of Gharbiah, Egypt. Breast J. 2009:15(4):432.

10. Levine PH, Veneroso $\mathrm{C}$. The epidemiology of inflammatory breast cancer. In: Seminars in oncology: 2008, vol. 35. Elsevier; 2008. p. 11-6.

11. Pogo BGT, Holland JF, Levine PH. Human mammary tumor virus in inflammatory breast cancer. Cancer. 2010;116(S11):2741-4.

12. Lê MG, Arriagada R, Bahi J, Pfeiffer F, Cammoun M, Tabbane F, Rubino C. Are risk factors for breast cancer similar in women with inflammatory breast cancer and in those with non-inflammatory breast cancer? Breast. 2006; 15(3):355-62.

13. Chang S, Parker SL, Pham T, Buzdar AU, Hursting SD. Inflammatory breast carcinoma incidence and survival. Cancer. 1998;82(12):2366-72.

14. Jimenez AM, Growney A, Behrens G, Corbridge C, Chapman DD, Usha L. Hereditary inflammatory breast cancer associated with BRCA2 mutation: a rare disease presentation in mother and daughter. Clin Adv Hematol Oncol. 2012;10(6):402-4.

15. Duke TJ, Jahed NC, Veneroso CC, Da Roza R, Johnson O, Hoffman D, Barsky $\mathrm{SH}$, Levine PH. A cluster of inflammatory breast cancer (IBC) in an office setting: additional evidence of the importance of environmental factors in IBC etiology. Oncol Rep. 2010;24(5):1277-84.

16. Sinn HP, Kreipe H. A brief overview of the WHO classification of breast tumors, 4th edition, focusing on issues and updates from the 3rd edition. Breast Care (Basel). 2013;8(2):149-54. 
17. Singletary SE, Allred C, Ashley P, Bassett LW, Berry D, Bland Kl, Borgen PI, Clark G, Edge SB, Hayes DF. Revision of the American joint committee on Cancer staging system for breast cancer. J Clin Oncol. 2002;20(17):3628-36.

18. Wolff AC, Hammond MEH, Hicks DG, Dowsett M, McShane LM, Allison KH, Allred DC, Bartlett JM, Bilous M, Fitzgibbons P. Recommendations for human epidermal growth factor receptor 2 testing in breast cancer: American Society of Clinical Oncology/College of American Pathologists clinical practice guideline update. Arch Pathol Lab Med. 2013;138(2):241-56.

19. Goldhirsch A, Winer EP, Coates AS, Gelber RD, Piccart-Gebhart M, Thürlimann B, Senn $\mathrm{H}-\mathrm{J}$, Members Panel. Personalizing the treatment of women with early breast cancer: highlights of the St Gallen international expert consensus on the primary therapy of early breast Cancer 2013. Ann Oncol. 2013;24(9):2206-23.

20. Dawood S, Lei X, Dent R, Gupta S, Sirohi B, Cortes J, Cristofanilli M, Buchholz $T$, Gonzalez-Angulo A. Survival of women with inflammatory breast cancer: a large population-based study. Ann Oncol. 2014;25(6):1143-51.

21. Labidi SI, Mrad K, Mezlini A, Ouarda MA, Combes JD, Abdallah MB, Romdhane KB, Viens P, Ayed FB. Inflammatory breast cancer in Tunisia in the era of multimodality therapy. Ann Oncol. 2008;19(3):473-80.

22. Chaher N, Arias-Pulido H, Terki N, Qualls C, Bouzid K, Verschraegen C, Wallace AM, Royce M. Molecular and epidemiological characteristics of inflammatory breast cancer in Algerian patients. Breast Cancer Res Treat. 2012;131(2):437-44.

23. Slaoui M, El Mzibri M, Razine R, Qmichou Z, Attaleb M, Amrani M. Detection of MMTV-like sequences in Moroccan breast cancer cases. Infectious Agents and Cancer. 2014:9(1):37.

24. Levine PH, Pogo BGT, Klouj A, Coronel S, Woodson K, Melana SM, Mourali N, Holland JF. Increasing evidence for a human breast carcinoma virus with geographic differences. Cancer. 2004;101(4):721-6.

25. Moslehi R, Freedman E, Zeinomar N, Veneroso C, Levine PH. Importance of hereditary and selected environmental risk factors in the etiology of inflammatory breast cancer: a case-comparison study. BMC Cancer. 2016;16(1):1

26. Schairer C, Li Y, Frawley P, Graubard BI, Wellman RD, Buist DS, Kerlikowske K, Onega TL, Anderson WF, Miglioretti DL. Risk factors for inflammatory breast cancer and other invasive breast cancers. J Natl Cancer Inst. 2013;105(18): 1373-84.

27. Soliman AS, Kleer CG, Mrad K, Karkouri M, Omar S, Khaled HM, Benider A-L, Ayed FB, Eissa SS, Eissa MS, et al. Inflammatory breast cancer in North Africa: comparison of clinical and molecular epidemiologic characteristics of patients from Egypt, Tunisia, and Morocco. Breast Dis. 2011;33(4):159-69.

28. Mejri N, Boussen H, Labidi S, Bouzaiene H, Afrit M, Benna F, Rahal K. Inflammatory breast cancer in Tunisia from 2005 to 2010: epidemiologic and anatomoclinical transitions from published data. Asian Pac J Cancer Prev. 2014;16(3):1277-80

29. Li J, Gonzalez-Angulo AM, Allen PK, Yu TK, Woodward WA, Ueno NT, Lucci A, Krishnamurthy S, Gong Y, Bondy ML, et al. Triple-negative subtype predicts poor overall survival and high Locoregional relapse in inflammatory breast Cancer. Oncologist. 2011;16(12):1675-83.

30. Lehmann BD, Bauer JA, Chen X, Sanders ME, Chakravarthy AB, Shyr Y, Pietenpol JA. Identification of human triple-negative breast cancer subtypes and preclinical models for selection of targeted therapies. J Clin Invest. 2011;121(7):2750-67.

31. Masuda H, Baggerly KA, Wang Y, Iwamoto T, Brewer T, Pusztai L, Kai K, Kogawa T, Finetti P, Birnbaum D. Comparison of molecular subtype distribution in triple-negative inflammatory and non-inflammatory breast cancers. Breast Cancer Res. 2013;15(6):R112.

32. Ben Hamida A, Labidi IS, Mrad K, Charafe-Jauffret E, Ben Arab S, Esterni B, Xerri L, Viens P, Bertucci F, Birnbaum D, et al. Markers of subtypes in inflammatory breast cancer studied by immunohistochemistry: prominent expression of P-cadherin. BMC Cancer. 2008:8(1):1-8.

33. Low JA, Berman AW, Steinberg SM, Danforth DN, Lippman ME, Swain SM. Long-term follow-up for locally advanced and inflammatory breast cancer patients treated with multimodality therapy. J Clin Oncol. 2004;22(20):4067-74.

\section{Ready to submit your research? Choose BMC and benefit from:}

- fast, convenient online submission

- thorough peer review by experienced researchers in your field

- rapid publication on acceptance

- support for research data, including large and complex data types

- gold Open Access which fosters wider collaboration and increased citations

- maximum visibility for your research: over $100 \mathrm{M}$ website views per year

At BMC, research is always in progress.

Learn more biomedcentral.com/submissions 